\title{
KETERAMPILAN MENULIS SURAT YANG BAIK DAN BENAR
}

\author{
Vidya Octa Sari *)
}

\begin{abstract}
In the daily life, someone always uses communication tools to connect and talk with others. One of the communication tools used is by writing letters. A letter is a communication tool in written form with the aim that someone can communicate to convey information, messages, questions or in accordance with the wishes of the author. In accordance with this objective, there are several requirements that must be taken into account in making the letter. In fact, there are many more mistakes that we often encounter in terms of tattooing the letter. For the diagnosis of this paper is made with the aim to know the systematic way of writing letters that are good and true. Information or messages that can be conveyed well by the readers.
\end{abstract}

\section{Key Words: Writing, Letter}

\section{PENDAHULUAN}

Salah satu bagian dari keterampilan menulis adalah menulis surat. Surat merupakan bagian yang tidak dapat terpisahkan dari aktivitas manusia dalam era modern ini. Surat adalah sarana untuk menyampaikan pikiran, isi hati, maksud, atau kehendak kepada orang lain melalui bahasa tulis dengan menggunakan kertas sebagai medianya. Surat dipandang sebagai alat komunikasi tulis yang efisien, efektif, ekonomis, dan praktis dibandingkan dengan komunikasi lisan. Surat juga dapat berfungsi sebagai alat untuk mewakil penulis. Dalam hal ini penulis tidak perlu bertatap muka langsung dengan orang yang dituju untuk menyampaikan informasi, melainkan telah diwakili oleh surat tersebut.

Pada era globalisasi sekarang ini, ternyata tidak menghilangkan peranan surat dalam menyampaikan gagasan yang akan disampaikan, baik dalam komunikasi biasa maupun resmi. Pada kenyataannya, masih banyak tenaga administrasi perkantoran, organisasi, lembaga, dan kalangan lainnya yang menggunakan surat sebagai alat komunikasi. Dalam menulis surat, penulis terlebih dahulu harus memahami bagianbagian surat, kegunaan surat, bahasa surat, dan langkah-langkah penyusunan surat.

Sebuah surat yang baik tentu harus disusun secara baik pula. Susunan surat tersebut secara keseluruhan terdiri atas bagian-bagian surat. Jika bagian-bagian surat tersebut tertulis secara benar dan berdasarkan aturan yang baik, surat yang dibuat itu pun akan menjadi sebuah surat yang baik pula.

Namun, terkadang masih banyak yang tidak mengerti apa itu surat, fungsi, 
bagian-bagian surat, jenis-jenis, bentuk dan bahasa surat yang baik dan benar. Banyak kesalahan yang sering ditemukan dalam halnya penulisan surat. Sebagaimana yang diketahui bahwa masih banyak masyarakat yang belum mengetahui bagaimana tata cara penulisan surat yang baik dan benar.Oleh karena itu, tulisan ini dibuat dengan tujuan untuk mengetahui sistematika cara penulisan surat yang baik dan benar serta agar dapat membedakan format dan jenis-jenis surat yang kita temui. Penulisan artikel ini diharapkan bermanfaat bagi pembaca terutama mahasiswa sebagai panduan dalam penentuan dan penulisan surat resmi maupun tidak resmi.

Masalah-masalah yang akan disampaikan dalam tulisan ini, yaitu tentang: pengertian keterampilan menulis, pengertian surat, fungsi surat, bagian-bagian Surat, jenis-jenis surat, syarat-syarat surat yang baik. Adapun tujuan tulisan ini, yaitu karena masih banyak masyarakat yang tidak mengetahui aturan atau tata cara menulis surat yang baik dan benar. Oleh karena itu, makalah ini dibuat dengan tujuan agar pembaca terampil menulis surat, terutama surat resmi.

\section{PEMBAHASAN}

\section{A. Keterampilan Menulis}

Menurut Suparno dan Yunus (2008:1.3) menulis merupakan suatu kegiatan penyampaian pesan (komunikasi) dengan menggunakan bahasa tulis sebagai alat atau medianya. Tarigan (2005:21) menyatakan bahwa menulis ialah menurunkan atau melukiskan lambang-lambang grafis yang menghasilkan suatu bahasa yang dipahami oleh seseorang sehingga orang lain dapat membaca dan memahami lambanglambang grafis tersebut.

Sejalan dengan pendapat di atas, Marwoto (1987:19) menjelaskan bahwa menulis adalah mengungkapkan ide atau gagasannya dalam bentuk karangan secara leluasa. Dalam hal ini, menulis itu membutuhkan skemata yang luas sehingga si penulis mampu meluangkan ide, gagasan, pendapatnya dengan mudah dan lancar.

Berdasarkan pendapat di atas dapat dikatakan bahwa keterampilan menulis merupakan sebuah proses untuk menuangkan atau menyampaikan suatu gagasan, ide, pendapat dalam bentuk bahasa tulis yang bertujuan untuk memberitahu, meyakinkan, atau menghibur pembaca.

\section{B. Pengertian Surat}

Surat merupakan suatu sarana komunikasi tertulis. Menurut Suprapro (2004:13) ditinjau dari sifat isinya, surat adalah jenis karangan paparan karena di dalamnya si pengirim mengemukakan maksud dan tujuan atau menjelaskan apa yang dipikirkan dan dirasakannya. Ditinjau dari wujud penuturannya, surat merupakan percapakan atau dialog yang tertulis dari 
suatu pihak kepada pihak penerima. kertas atau lainnya. Jadi, fungsi utama surat Selanjutnya ditinjau dari fungsinya, surat adalah sebagai alat komunikasi tertulis. adalah komunikasi atau informasi antara si Kemudian menurut Soedjito dan Solchan pengirim dan si penerima yang berwujud (2004:2), surat berfungsi sebagai: tulisan dalam kertas atau yang lainnya. $\quad$ 1. alat komunikasi;

Surat merupakan suatu model 2. alat bukti tertulis; komunikasi tertulis yang memungkinkan 3. alat bukti historis; seseorang saling memberikan informasi atau 4. alat pengingat; mempertukarkan ide. Surat adalah media 5. duta organisasi, dan; komunikasi yang berupa tulisan, yang berisi informasi, pesan, pertanyaan, atau tanggapan sesuai dengan keinginan penulis surat (Iis Sopyan, 2008:1). Diana Nababab menyatakan bahwa surat merupakan alat komunikasi yang disajikan secara tertulis. Surat harus disajikan dengan baik karena surat secara tidak langsung memberikan gambaran tentang pribadi pengirimnya (2008:133).

6. pedoman kerja.

Pendapat lain tentang fungsi surat dikemukakan oleh Djanewai (dalam Rahardi, 2008:14). Ia mengatakan bahwa fungsi surat itu adalah sebagai berikut:

1. sebagai alat dokumentasi tertulis;

2. sebagai duta institusi dan duta penulisan;

3. sebagai medium komunikasi dan interaksi;

4. sebagai otaktata suaha dalam perkantoran;

Berdasarkan beberapa pendapat di atas dapat disimpulkan, bahwa surat merupakan alat komunikasi yang berisi tulisan, pernyataan, suatu kabar, harapan, perintah, laporan dan tanggapan yang sesuai dengan keinginan dari penulis kepada seseorang, pihak satu ke pihak lain, atau antara lembaga ke lembaga lainnya yang dikehendakinya. Dengan kata lain, surat menyurat itu merupakan salah satu kegiatan berbahasa dalam bentuk komunikasi tertulis.

\section{Fungsi Surat}

Menurut Suprapto (2004:15), fungsi utama surat adalah sebagai alat komunikasi antara dua pihak yang berupa tulisan dalam

5. sebagai barometer kemajuan institusi.

Berdasarkan pendapat para ahli di atas dapat disimpulkan bahwa pada dasarnya fungsi surat adalah sebagai alat komunikasi antara dua pihak, seperti antara lembaga, instansi sebagai pedoman dalam bertindak untuk kemajuan institusi tersebut. Surat dijadikan sebagai alat penyampai informasi dari penulisnya kepada pembaca/ penerimanya. Sebagai alat komunikasi surat tidak hanya bersifat satu arah, melainkan juga dua arah dan ke segala arah. Artinya, surat juga dapat dibalas (surat balasan) sebagai timbal balik dan surat juga dapat dibuat/ditujukan kepada lebih dari satu orang (surat edaran, pengumuman, surat pembaca 
pada surat kabar dan lain-lain).Surat sebagai wakil penulis, dalam hal ini penulis tidak perlu langsung bertatap muka dengan orang yang dituju. Jadi, berkomunikasi dengan surat dapat dilakukan dari jarak jauh sehingga dapat menghemat waktu, tenaga, dan biaya. Surat juga dapat dijadikan bukti tertulis untuk berbagai keperluan. Misalnya, pada surat-surat perjanjian, surat waris dan sebagainya. Segala jenis surat juga dapat diabadikan/diarsipkan untuk kepentingankepentingan lain kelak di kemudian hari.

\section{Bagian-Bagian Surat}

Suprapto (2004:54) menjelaskan dalam menulis surat, bagian-bagian surat yang harus diperhatikan adalah sebagai berikut.

\section{a. Kepala Surat/ Kop Surat}

Kepala surat merupakan identitas singkat tentang kantor, perusahaan, organisasi, dan sejenisnya yang mengirimkan surat resmi. Bagian ini berfungsi untuk mengetahui dengan mudah nama dan alamat serta keterangan lain mengenai identitas lembaga si pengirim surat. Kepala surat bisa juga disebut dengan kop surat merupakan bagian teratas dalam sebuah surat. Fungsi penyertaan kepala surat tersebut tidak terlepas dari pemberian informasi mengenai nama, alamat, kegiatan dari lembaga tersebut serta juga bisa menjadi alat promosi. Bagian surat yang pertama ini berisi:
- Logo atau lambang dari sebuah instansi, lembaga, perusahaan atau organisasi,

- Nama instansi, lembaga, perusahaan, atau organisasi tersebut,

- Alamat instansi, lembaga, perusahaan, atau organisasi tersebut,

- Nomor telepon, kode pos, alamat email atau alamat web.

Biasanya setelah penulisan kepala surat atau kop surat terdapat sebuah garis horizontal pemisah yang memisahkan antara kepala surat dengan bagian-bagian surat yang lain seperti tempat dan tanggal pembuatan.

\section{b. Tempat dan Tanggal Surat}

Tanggal surat menunjukkan surat itu dibuat. Bagian ini berfungsi memudahkan petugas dalam pengarsipan surat. Selain itu tanggal surat berguna untuk mengetahui batas waktu dan cepat lambatnya penyelesaian masalah yang dipersoalkan dalam surat. Pencantuman tempat dan tanggal surat tersendiri ditujukan untuk memberikan informasi mengenai tempat dan tanggal penulisan surat tersebut. Untuk tempat biasanya tidak dicantumkan kembali jika tempat sudah ditulis di kepala surat yang berupa alamat instansi. Tapi bagi surat bukan resmi yang tidak memiliki kepala surat, wajib menuliskan tempat di bagian surat ke 2 ini.

Contoh:

17 Oktober $1990 \quad 06$ Februari 2018 


\section{c. Nomor Surat}

Surat-surat dinas atau surat resmi yang dikeluarkan harus diberi nomor surat dan kodenya. Sebuah surat resmi yang mewakili sebuah lembaga, instansi, perusahaan atau organisasi biasanya menggunakan penomoran terhadap surat yang dikeluarkan atau yang diterima. Nomor surat biasanya meliputi nomor urut penulisan surat, kode surat, tanggal, bulan dan tahun penulisan surat. Penomoran surat tersebut berfungsi untuk:

- Memudahkan pengaturan, baik untuk penyimpanan maupun penemuannya kembali apabila diperlukan,

- Mengetahui jumlah surat yang diterima dan yang dikeluarkan oleh organisasi, lembaga atau perusahaan,

- Memudahkan pengklasifikasian surat berdasarkan isinya,

- Penunjukan secara akurat sumber dalam hubungan surat menyurat,

Contoh:

Nomor: 023/PMR/05/12/2018

Nomor: 042/PRMK/28/08/2018

\section{d. Lampiran}

Bagian lampiran merupakan bagian penjelas yang menginformasikan bahwa ada sejumlah berkas atau dokumen yang disertakan dalam surat tersebut. Jika tidak terdapat berkas atau dokumen yang dilampirkan, bagian lampiran bisa ditiadakan.

\section{e. Hal/Perihal}

Surat-surat resmi atau surat dinas yang baik selalu dilengkapi dengan bagian hal/perihal. Hal atau perihal tersebut memuat isi pokok surat tersebut. Karena merupakan intisari isi surat, hal/perihal cukup ditulis sesingkat mungkin. Namun, dapat dipahami dan menggunakan huruf kapital pada awal kata dan berjenis kata benda bukan kata kerja.

Contoh :

Hal : Penawaran Harga Buku

Perhal: Penagihan Pembayaran

\section{f. Alamat Surat}

Penulisan alamat pada halaman surat sebaiknya samalengkapnya seperti penulisan pada sampul surat. Ada beberapa hal yang harus diperhatikan dalam menulis alamat dalam ini, hal-hal tersebut adalah sebagai berikut:

- Kata "kepada" pada alamat dalam sebenarnya tidak harus ada. Kata "kepada" dirasa berlebihan karena sudah ada kata "Yth./ yang terhormat"

- Menggunakan kata "Yang terhormat" yang bisa disingkat menjadi "Yth."

- Menggunakan kata "Bapak", "Ibu" atau "Sdr" jika yang dituju adalah seseorang bukan nama instasi. Kata "Bapak, Ibu, Sdr" selalu ditulis dengan huruf kapital diawal kata dan diikuti oleh nama orang.

- Di setiap baris pada bagian alamat dalam tidak diakhiri oleh tanda titik. 
- Menuliskan alamat orang atau lembaga yang dituju, lengkap lebih bagus.

Contoh:

Yth.Direktur PT Aneka

Jalan Raden Intan 11

Jakarta

\section{g. Salam Pembuka}

Penulisan salam pembuka dimulai dari margin kiri, bukan di tengah-tengah dan tidak pula menjorok ke dalam seperti paragraf. Salam pembuka yang berfungsi sebagai sapaan dalam surat. Salam pembuka ditulis dengan huruf kapital di awal dan diakhiri oleh tanda koma (,).

Contoh :

Dengan hormat,

Bapak yang terhormat,

Salam hormat,

Assalamualaikum wr.wb.

Salam bahagia

\section{h. Isi Surat}

- Pembuka

Pembuka merupakan alenia pertama yang berfungsi sebagai pengantar atau pendahuluan terhadap informasi yang disampaikan di alenia isi.

- Isi

Alendia isi berisi informasi yang akan disampaikan.

- Penutup
Selanjutnya alenia penutup ini berisi ucapan terima kasih atau harapan dari penulis surat kepada pembaca surat.

\section{i. Salam Penutup}

Salam penutup merupakan penutup surat yang biasanya menggunakan kata: "Hormat saya, Hormat kami, Wassalam". Penulisan salam penutup tersebut seperti salam pembuka, diawali oleh huruf kapital dan diakhiri oleh tanda koma.

\section{j. Nama Jelas Pengirim dan Tanda tangan}

Pengirim surat dinas adalah orang yang bertanggung jawab terhadap lembaga atau organisasi yang dipimpinnya. Identitas pengirim dalam surat dinas, biasanya terdiri atas lima unsur, yaitu:

a. jabatan pengirim;

b. tanda tangan pengirim;

c. stempel/cap dinas;

d. nama terang pengirim;

e. keterangan lain, misalnya NIP;

\section{k. Tembusan}

Tembusan merupakan bagian surat yang menunjukkan pihak atau orang lain yang juga berhak mendapatkan surat tersebut.

Contoh:

Tembusan:

1. Yth. Direktur PT ABDI, Jakarta

2. Yth. Direktur Mandiri, Jakarta

3. Arsip 
- Contoh surat

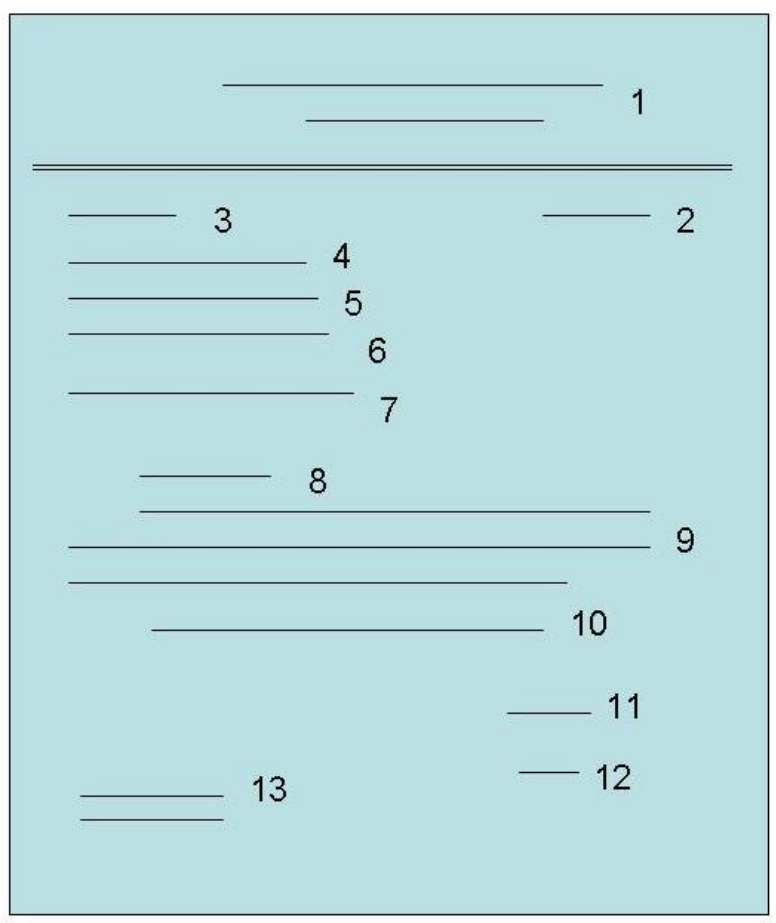

- Bagian surat

1. Kepala surat

2. Tanggal surat

3. Nomor surat

4. Sifat surat

5. Lampiran

6. Hal /perihal

7. Alamat dalam

8. Kalimat pembuka

9. Isi surat

10. Kalimat penutup

11. Nama Jabatan

12. Nip /tanda tangan/cap initial

13. Tembusan

\section{E. Jenis-Jenis Surat}

Secara umum surat digolongkan menjadi tiga fungsi atau tiga jenis, yaitu surat resmi, surat pribadi, dan surat niaga .

\section{Surat Resmi}

Surat resmi adalah surat yang biasa digunakan untuk kepentingan resmi, baik perseorangan, instansi, maupun organisasi. Contoh dari surat resmi adalah surat undangan, surat edaran, dan surat pemberitahuan. Adapun ciri-ciri dari surat resmi ini adalah:

1. menggunakan kop surat apabila dikeluarkan organisasi.

2. ada nomor surat, lampiran, dan perihal.
3. menggunakan salam pembuka dan penutup yang lazim;

4. penggunaan ragam bahasa resmi;

5. Menyertakan cap atau stempel dari lembaga resmi.

\section{Surat Pribadi}

Surat pribadi adalah surat yang digunakan untuk kepentingan pribadi atau dapat dikatakan surat yang tujuannya hanya untuk seseorang. Surat ini ditujukan antara sesama teman atau keluarga. Ciri-ciri surat pribadi, yaitu tidak menggunakan kop surat, tidak ada nomor surat, salam pembuka dan penutup bervariasi, menggunakan bahasa bebas yang sesuai keinginan dari si penulis, dan format tulisan surat bebas. Surat ini tidak termasuk surat resmi, tetapi dalam surat 
pribadi. Tentunya surat resmi harus memperhatikan etika dan sopan santun dalam penulisannya tidak boleh menggunakan bahasa yang semaunya. Contoh dari surat pribadi adalah surat izin dari orang tua untuk sekolah, surat cinta dari pasangan, surat undangan ulang tahun, surat kepada sahabat, dan lain-lain..

\section{Surat Niaga}

Surat niaga adalah surat yang biasa digunakan bagi badan yang menyelenggarakan kegiatan usaha niaga seperti usaha industri, bisnis, dan usaha jasa. Biasanya surat niaga dibuat oleh perusahaan untuk mencari keuntungan. Surat ini sangat berguna dalam membangun hubungan dengan pihak luar sehingga harus disusun dengan baik dan benar. Ada beberapa macam yang termasuk ke dalam surat niaga, yaitu surat jual beli, kwitansi, dan perdagangan. Surat niaga juga format tulisannya hampir sama dengan surat resmi.

\section{F. Syarat-syarat Surat yang Baik}

Surat yang dapat dikatakan baik adalah surat yang ditulis dengan memenuhi syaratsyarat penyusunan surat yang baik. Soedjito dan Solchan (2004:2) mengatakan bahwa syarat-syarat surat yang baik sebagai berikut.

a. Surat harus disusun dengan teknik penyusunan surat yang benar. b. Isi surat harus dinyatakan secara ringkas, jelas, dan eksplisit. Hal itu menguntungkan kedua pihak.

c. Bahasa yang digunakan haruslah bahasa yang benar/baku sesuai dengan kaidah bahasa Indonesia, baik tentang ejaan, pemilihan kata, bentuk kata, maupun kalimatnya.

Finoza (dalam Rahardi, 2008:44), mengungkapkan bahwa kriteria surat yang baik adalah sebagai berikut.

a. Menggunakan kertas yang tepat dari segiukuran, jenis, dan warna.

b. Menggunakan bentuk surat yang standar.

c. Menggunakan bahasa Indonesia yang baik dan benar terutama surat resmi.

d. Menggunakan bahasa yang jelas.

e. Menyajikan fakta yang benar dan lengkap.

f. Tidak menggunkan singkatan, kecuali yang lazim dipakai dalam suratmenyurat.

g. Menggunakan bahasa yang sopan dan hormat.

h. Tidak menggunakan kata-kata yang sulit dan istilah yang belum memasyarakat.

Berdasarkan beberapa pendapat di atas, dapat disimpulkan bahwa kriteria surat yang baik itu terdiri atas:

(1) ditulis dengan menggunakan bahasa Indonesia yang baik dan benar terutama surat resmi,

(2) menggunakan bahasa yang jelas dan mudah dipahami oleh pembaca, 
(3) menggunakan pilihan kata yang tepat,

(4) taat terhadap EYD,

(5) menggunakan kalimat efektif,

(6) menyajikan isi surat berdasarkan fakta dan lengkap,

(7) menggunakan bentuksurat yang resmi atau yang lazim digunakan.

\section{SIMPULAN}

Keterampilan menulis merupakan sebuah proses untuk menuangkan atau menyampaikan suatu gagasan, ide, pendapat dalam bentuk bahasa tulis yang bertujuan untuk memberitahu, meyakinkan, atau menghibur pembaca. Salah satu keterampilan menulis, yaitu menulis surat. Surat merupakan alat komunikasi yang berisi tulisan, pernyataan, suatu kabar, harapan, perintah, laporan dan tanggapan yang sesuai dengan keinginan dari penulis kepada seseorang, pihak satu kepihak lain, atau antara lembaga ke lembaga lainnya yang dikehendakinya.

Dengan kata lain, surat menyurat itu merupakan salah satu kegiatan berbahasa dalam bentuk komunikasi tertulis, yang dapat membantu memperlancar tercapainya tujuan suatu organisasi. Diharapkan pada saat menulis surat diperhatikan langkahlangkahnya agar tidak terjadi kesalahan dalam pembuatannya. Dalam menulis surat, penulis terlebih dahulu harus memahami bagian-bagian surat, kegunaan surat, bahasa surat, dan langkah-langkah penyusunan surat.

Sebuah surat yang baik tentu harus disusun secara baik pula. Susunan surat tersebut secara keseluruhan terdiri atas bagian-bagian surat. Jika bagian-bagian surat tersebut tertulis secara benar dan berdasarkan aturan yang baik, surat yang dibuat itu pun akan menjadi sebuah surat yang baik pula. Oleh karena itu, dengan adanya surat menyurat yang baik dan rapi maka dapat mendukung tercapainya tujuan organisasi, yaitu bisa bertahan dan bisa tumbuh berkembang.

\section{DAFTAR RUJUKAN}

Finoza, Lamudin. 2008. Komposisi Bahasa Indonesia. Jakarta: Diksi Insan Mulia.

Nababan, Diana. 2008. Intisari Bahasa Indonesia. Kawan Pustaka.

Rahardi, R.K. 2008. Surat-Menyurat Dinas. Yogyakarta: Pustaka Book Publisher.

Suparno dan Yunus,M. 2008. Keterampilan Dasar Menulis. Jakarta: Universitas Terbuka.

Suprapto. 2004. Pedoman Lengkap Surat Menyurat Bahasa Indonesia. Surabaya: Indah.

Soedjito \& Solchan. 2004. Surat-Menyurat Resmi Bahasa Indonesia.

Bandung: Remaja Rosdakarya. 
Tarigan, Hendry Guntur. 2005. Menulis sebagai Keterampilan Berbahasa. Bandung: Angkasa.

https://frendyrusniady.wordpress.com/2012/ 03/31/makalah-surat-menyurat/

http://abdullohaja.blogspot.com/2014/01/ma kalah-surat-resmi.html

https://febianputra.wordpress.com/2012/07/0 1/pengertian-surat-macam-macamdan-contoh-surat/ 